\title{
EFFECTS OF HEDONIC - UTILITARIAN MOTIVES AND LIFE STYLE ON ATTITUDINAL-BEHAVIORAL LOYALTY*
}

\author{
BAHTIŞEN KAVAK** \\ Hacettepe University \\ CANAN ERYİĞİT**** \\ Hacettepe University
}

\author{
ÖZNUR ÖZKAN TEKTAŞ**** \\ Hacettepe University
}

\author{
PINAR BAŞGÖZE****** \\ Hacettepe University
}

\begin{abstract}
This study investigates whether the effects of hedonic and utilitarian buying motives on attitudinal and behavioral loyalty vary for convenience, shopping, and specialty product types, with a control for consumers' life styles. Data was collected from 835 Turkish households. MANOVA was used to test the effects of hedonic and utilitarian buying motives. The results showed that utilitarian buying motives have significant effects on attitudinal loyalty for shopping and specialty products. Hedonic motives have significant effects on attitudinal loyalty for shopping products and on behavioral loyalty for specialty products. According to MANCOVA results, life styles do not have controlling effects.
\end{abstract}

Key words: hedonic motives, utilitarian motives, loyalty, life style, Turkey.

\section{HAZCI - FAYDACI MOTIVLERIN VE YAŞAM TARZININ TUTUMSAL VE DAVRANIŞSAL SADAKAT ÜZERINDEKİ ETKILLERI}

\section{$\ddot{O Z E T}$}

Bu çalışmada, yaşam tarzının etkisi kontrol edilerek hazcı ve faydacı motivlerin tutumsal ve davranışsal sadakat üzerindeki etkisinin kolayda, be ğenmeli ve özellikli mallar için değissip de ğişmediği incelenmiştir. Veri 835 hanehalkından toplanmıştır. Hazcı ve faydacı motivlerin etkisini ölçmek için MANOVA kullanılmıştır. Sonuçlara göre, faydacı satın alma motivleri, be ğenmeli ve özellikli mallarda tutumsal sadakati etkilemektedir. Hazcı motivler ise beğenmeli mallarda tutumsal sadakati; özellikli mallarda davranıssal sadakati etkilemektedir. MANCOVA sonuçları da yaşam tarzının söz konusu bu ilişkileri kontrol etmediğ̈ini göstermiştir.

Anahtar kelimeler: hazcı motivler, faydacı motivler, sadakat, yaşam tarzı, Türkiye.

\footnotetext{
* The authors would like to thank the rewievers very much for their appreciated comments on the earlier manuscript of the study.

** Bahtışen Kavak is a Professor in the Department of Business Administration at Hacettepe University, 06800, Beytepe, Ankara, Turkey. E-mail: bahtisenkavak@gmail.com

*** Öznur Özkan Tektaş is an instructor in the Department of Business Administration at Hacettepe University, 06800, Beytepe, Ankara, Turkey. E-mail: oznuro@ hacettepe.edu.tr

**** Canan Eryiğit is an instructor in the Department of Business Administration at Hacettepe University, 06800, Beytepe, Ankara, Turkey. E-mail: canand@ hacettepe.edu.tr

***** Pınar Başgöze is an instructor in the Department of Business Administration at Hacettepe University, 06800, Beytepe, Ankara, Turkey. E-mail: pinaran@hacettepe.edu.tr
}

Boğaziçi Journal Vol. 24, no. 1-2 (2010), pp. 21-40. 
Brand loyalty is strategically important for managing brands (Amine, 1998) and for profitability (Srinivasan et al., 2002) because brand loyalty leads to various marketing advantages such as reduced marketing cost, greater market share, favorable word of mouth (Chaudhuri and Holbrook, 2001) and willingness to pay much more than the normal value (Reichheld and Sasser, 1990). There may be many reasons why consumers buy the same brand repeatedly, among them brand reputation, risk aversion, social group influences (Gounaris and Stathakopoulos, 2004), brand personality (Kim et al., 2001) and hedonic and utilitarian buying motives (Scarpi, 2005; Trijp, 1995). Among these, hedonic and utilitarian buying motives can be considered as predictors of consumer attitudes and behaviors (Voss et al., 2003). Hedonic and utilitarian buying motives have been investigated as much focused shopping motives (Kaufman-Scarborough and Lindquist, 2002) which represent a useful basis for understanding consumer outcomes such as satisfaction and loyalty (e.g. Childers, Carr, Peck Carson, 2001). Consumer choice and use of different products and services are driven by both utilitarian (UT) and hedonic (HED) considerations (Storgards, Tuunainen and Öörni, 2009). However, there are few studies (e.g. Carroll and Ahuvia, 2006; Griffin et al., 2000; Scarpi, 2005) examining the direct effects of these motives on loyalty. Although the loyalty concept should be considered not only as repeated purchases, but also as a consumer attitude (Sheth and Park, 1974), none of these studies have investigated the impact of hedonic and utilitarian buying motives on behavioral and attitudinal loyalty.

On the other hand, products themselves may have differing levels of hedonic or utilitarian benefits in their nature according to their attributes, and these benefits may influence loyalty dimensions differently in the consumers' minds (Carroll and Ahuvia, 2006). For instance, buyers who tend to have a low brand loyalty for convenience goods are not strongly brand loyal for shopping goods (Fernie et al., 2003: 250) but do have a strong brand loyalty for specialty goods (Finch et al., 2006:36). Therefore, the effects of hedonic and utilitarian buying motives on attitudinal and behavioral loyalty need to be investigated for different product categories such as convenience, shopping and specialty. In addition, life styles that have been previously found (Matzler et al., 2005) to affect loyalty may be included in order to control the influence of hedonic and utilitarian tendencies.

The purpose of this study is to investigate the effects of hedonic and utilitarian motives along with life styles on behavioral and attitudinal loyalty depending on the type of product, convenience, shopping, or specialty.

Thus the present study contributes two new approaches to the literature. First, the existing literature on the influence of hedonic and utilitarian motives on brand loyalty is extended separately for attitudinal and behavioral loyalty. Second, this influence is investigated for convenience, shopping, and specialty products by controlling life styles which have been widely investigated as the predictors of brand loyalty.

The rest of the paper is organized as follows: First, the references in literature on brand loyalty, hedonic and utilitarian buying motives, brand loyalty and buying motives for different product types and life styles are provided. Next, the methodology of the study containing details of the survey and data is presented. Then, findings of the study are provided. The conclusion and some comments for marketing professionals are presented at the last section of the study. 


\section{BRAND LOYALTY: ATTITUDINAL - BEHAVIORAL}

There is an ongoing debate about the definition of loyalty. There are two approaches to the conceptualization of brand loyalty, namely, stochastic (behavioral) and deterministic (attitudinal) (Odin et al., 2001). A stochastic approach defines loyalty as a behavior which refers to repeated purchases of the brand (Chaudhuri and Holbrook, 2001) and determines the loyalty status of a given consumer by observing his or her purchase record (Dubois and Laurent, 1999). With the same point of view, Jacoby and Kyner (1973) define loyalty as “(1) the biased (non-random), (2) behavioral responses (i.e. purchase), (3) expressed over time, (4) by some decision making unit, (5) with respect to one or more alternative brands out of a set of such brands, and (6) is a function of psychological (decision making/evaluative) processes." These definitions suggest that repeat purchasing and brand loyalty are the same and only repeat purchasing can capture the loyalty of a consumer towards a brand (Bandyopadhyay and Martell, 2007). However, the behavioral approach does not differentiate between various buying situations and personal motives; hence it is criticized as being static and lacking conceptual bases (Amine, 1998). For instance, Sheth and Park (1974) propose that the frequency or pattern of repeated brand purchase behavior is not sufficient to represent brand loyalty since it is a multidimensional construct including distinct psychological processes. They also state that loyalty can exist at the non-behavioral level for some products that consumers never buy. Dick and Basu (1994) emphasize the need to extend brand loyalty to include attitudinal influences as well.

The deterministic approach covers this non-behavioral side of the loyalty. According to it, loyalty is more than repeated purchases (Jacoby and Kyner, 1973) and includes some attitudes of consumers (Kim et al., 2006). Dick and Basu (1994) suggest that incorporating relative attitudes will increase the predictive ability of loyalty models. The attitudinal component refers to the strong internal disposition of consumers to continue buying the same brand (Amine, 1998). Similarly, Sheth and Park (1974) define brand loyalty as "a positively biased emotive, evaluative and/or behavioral response tendency toward a branded, labeled or graded alternative or choice by an individual in his capacity as the user, the choice maker and/or the purchasing agent."

Thus, it can be concluded that brand loyalty has two aspects: behavioral and attitudinal. Behavioral loyalty refers to repeated purchases of the brand. Attitudinal loyalty is, however, the level of commitment of the average consumer toward the brand (Chaudhuri and Holbrook, 2001) and reflects favorable expressions of preference for the brand (Dubois and Laurent, 1999).

The factors affecting brand loyalty have been widely examined in the literature (Amine 1998; Kim et al. 2001; Gounaris and Stathakopoulos, 2004; Kavak and İbrahimoğlu, 2006). Amine (1998) classifies antecedents of loyalty as indirect and direct sources. Indirect sources are involvement and satisfaction which influence loyalty through mediating variables. Direct sources are perceived differences among alternatives, perceived risk, brand sensitivity and brand attachment/liking. Antecedent factors can also be classified into three groups (Gounaris and Stathakopoulos, 2004): brand characteristics, such as brand reputation, availability of substitute brands (Gounaris and Stathakopoulos, 2004), and brand personality (Kim et al. 2001); social factors, such as social group influences and peers' recommendations; and consumer characteristics such as risk aversion, variety seeking (Gounaris and Stathakopoulos, 2004), identification of consumers with a brand, word of mouth (Kim et al. 2001), self concept, self-monitoring (Kavak and İbrahimoğlu, 2006), and hedonic and utilitarian buying motives (Scarpi, 2005; Trijp, 1995). 


\section{BUYING MOTIVES: UTILITARIAN - HEDONIC}

Among the consumer characteristics mentioned above, hedonic and utilitarian buying motives can be considered as better for understanding attitudinal and behavioral predictors of consumers (Wang et al., 2000). In other words, determination of the hedonic or utilitarian values that consumers attribute to a product makes consumer responses to marketing decisions more predictable (Dhar and Wertenbroch, 2000). Moreover, the relative dominance of the hedonic/utilitarian basis in product or brand attitudes moderates the effectiveness of various marketing strategies (Dube et al., 2003), as, for instance, if they are considered to be useful segmentation variables (Scarpi, 2005).

According to the traditional economic approach, products are objects that maximize a consumer's utility measured by a product's tangible attributes (Hirschman and Holbrook, 1982). This approach may be appropriate when tangible attributes are the primary determinant of the value of the product. However, this approach is inappropriate for some products that are selected and used based on satisfying emotional wants (Hirschman and Holbrook, 1982). Especially in the last decade, an increasing number of studies (e.g. Babin et al., 1994; Griffin et al., 2000; Jin, et al., 2003) have mentioned the importance of recognizing intangible and emotional causes in order to understand completely the purchasing behavior of consumers. It is stated that the reason or motives underlying consumption behavior can be clarified by two complex influences: utilitarian and hedonic (Babin et al., 1994; Batra and Ahtola, 1991).

The utilitarian dimension emphasizes the perceived functional impact on physical performance features of products in choice behavior (Wang et al., 2000). As defined by Athola (1985), the "utilitarian aspect of an attitude toward a behavior relates to usefulness, value, and wiseness of the behavior as perceived by the consumer." Thus, the utilitarian dimension is related to necessity rather than to recreation, and is often described in terms commonly used to evaluate work performance, e.g. success and accomplishment (Scarpi, 2005).

The hedonic dimension, on the other hand, relates to the pleasure experienced or anticipated from the behavior (Ahtola, 1985). Hirschman and Holbrook (1982) define hedonic consumption as "those facets of consumer behavior that relate to the multisensory, fantasy and emotive aspects of one's experience with products." Thus, it includes fun, enjoyment, fantasy, entertainment, freedom, excitement, involvement, new product information acquisition, and escapism from routine life (Jin et al., 2003). Likewise, Christmas shoppers have previously described themselves as "kids in a candy store" when engaged in holiday shopping, often expressing excitement, increased arousal, and a deep sense of enjoyment in shopping for others (Fischer and Arnold, 1990).

\section{BRAND LOYALTY AND BUYING MOTIVES FOR DIFFERENT PRODUCT TYPES}

As indicated before, consumer loyalty may vary for different product types. For example, convenience goods are relatively inexpensive goods which are bought for meeting ordinary needs without a lot of thought before purchase since these customers are confident about product qualities, uses and attributes. Therefore buyers tend to have a low brand loyalty for these goods. Shopping goods are the more expensive and more complex goods which the customer wants to evaluate and distinguish 
between competing or complementing goods. Customers are relatively confident about the attributes, qualities, and uses of these goods, but are not strongly brand loyal and therefore want to "shop around" to compare quality, price and features (Fernie et al., 2003: 250). Specialty goods are those for which the buyer has a strong brand loyalty (Finch et al., 2006: 36).

When it comes to buying motives, in the marketing literature there is evidence (e.g. Griffin et al., 2000; Chaudri and Holbrook, 2001; Scarpi, 2005; Chitturi et al., 2008) of direct and indirect effects of hedonic and utilitarian buying motives on brand loyalty. For example, Chitturi et al., (2008) state that hedonic and utilitarian motives influence loyalty through the mediating roles of post-consumption emotions such as cheerfulness, excitement, and safety. These emotions are considered as sources of delight and satisfaction which in turn influence repurchase intentions. Hedonic benefits of a product lead to cheerfulness and excitement which affect word of mouth recommendations through the mediating role of delight. Utilitarian benefits lead to confidence and security which likewise affect word of mouth and repurchase intentions through the mediating role of satisfaction (Chitturi et al., 2008).

Studies (e.g. Griffin et al., 2000; Scarpi, 2005; Carroll and Ahuvia, 2006) explaining the direct relationship between buying motives and brand loyalty are relatively rare and conflicting. Studies in environmental psychology have shown that affective experiences in the store can be important antecedents of approach or avoidance motivations, such as repatronage intentions (Donovan and Rossiter, 2003); therefore hedonic values should be related to repatronage intentions. Retail research has provided empirical support for this (Wakefield and Barnes, 1996; Scarpi, 2005). Scarpi (2005) found that hedonic consumers are more likely to purchase again in the same shop and search less actively for different stores. On the other hand, they are motivated toward switching brands when they are in a variety-seeking tendency (Trijp, 1995; Hirschman, 1980) since their behaviors are likely to be motivated by exploration, novelty, and variety (Leavitt and Walton, 1975; Trijp et al., 1996; Wang et al., 2000). It is stated similarly that consumers with weaker hedonic values tend to be value conscious and display intentions for repetitive behavior; consequently, they are less likely to change brands or try new products (Robertson, 1967; Raju, 1980; Lichtenstein et al., 1990).

Utilitarian motives are supposed to have positive effects on brand loyalty. Utilitarian consumers may be more loyal since utilitarian consumers will receive more time benefit, less perceived risk and searching by purchasing the brand with which they are familiar (Scarpi, 2005). However, Scarpi (2005) found that task oriented consumers' intentions to shop again in the same shop are rather weak.

These conflicting findings may be due to the types of the products examined. This is because the role and effect of hedonic and utilitarian buying motives on choice behavior and on loyalty may vary depending on some attributes of the products such as price and frequency of purchase.

When price is considered as one attribute of a product, it is assumed that paying a high price, or having the ability to pay a high price, may lead to ostentation or pleasure, thus giving consumers a hedonic feeling. In contrast, paying a low price for some particular products may be considered as an economic benefit (Mano and Elliott, 1997). Jin et al. (2003) state that consumers may be unwilling to pay a high price for durable goods while they may experience excitement when they pay a high price for an apparel product. This difference may be due to symbolic meanings of the products that produce hedonic motivations among individuals (Hirschman and Holbrook, 1982; Jin et al., 2003; Kaul, 2006) and also have some rational consequences from the acquisition of the product. 
When the frequency of purchasing and the degree of involvement are considered, Kaul (2006) found that routinely purchased products that are simple and have easily completed purchasing processes, such as coffee, are associated with utilitarian motives. On the contrary, products that require a high involvement, a high information search and usually have a high price, such as cell phones, are related to hedonic motives.

Based on the degree of purchase frequency, price and involvement, consumer goods are classified into three well-known categories as convenience, shopping and specialty products. Convenience products are goods that consumers usually need to purchase frequently with a minimum effort. They are comparatively low-priced goods that are immediately purchased without making much comparison or search (Holton 1958). Shopping products are "those consumer goods which the customer, in the process of selection and purchase, characteristically compares on such bases as suitability, quality, price, and style." (American Marketing Association, 1948). For shopping goods, the consumers' searching costs in terms of time, money, and effort are relatively larger than for convenience goods. The gain from making price and quality comparisons may consist of the enjoyment of shopping as well as the acquisition of a "better buy" (Holton, 1958). Lastly, specialty products are goods that have a particular attraction for a significant group of buyers so that they are willing to make a special purchasing effort (Holton, 1958); they usually have a high price, and are purchased rarely.

The above discussion leads to the following research questions:

RQ1: Do effects of hedonic and utilitarian motives on attitudinal brand loyalty vary depending on the product type, namely, convenience, shopping, and specialty?

RQ2: Do effects of hedonic and utilitarian motives on behavioral brand loyalty vary depending on the product type, namely, convenience, shopping, and specialty?

\section{LIFE STYLE}

The life style concept includes "the products one buys, how one uses them, how one thinks about them, and how one feels about them" (Spillan, Kucukemiroglu and de Mayolo, 2008: 44). Life style has been generally used in market segmentation since it is highly appropriate to predict behavioral and attitudinal differences among market segments (Füller and Matzler, 2008).

For instance, life style is useful in predicting brand loyalty (Goldberg, 1982). In his study on Canadian consumers, Goldberg proved that life style is significantly related to brand loyalty where loyalty is measured as attitudes toward a brand and purchase behavior.

Consumer life style is also related to brand preference and brand benefits. The study of Orth et al. (2004) on craft beer brands showed that life style segments differed with respect to five dimensions of brand benefits, namely, functional, price/value for money, social, positive and negative emotional benefits. For instance "lazy opportunists" care little for positive emotions. "Introvert individuals" do not give importance to social benefit. There are also significant differences in brand preferences among life style segments according to the results of the study. This may be related to the argument that consumers often use brand names to express their life styles (Wang et al., 2000). 
In addition to these influences, hedonic and utilitarian benefits differ on the basis of life style. Utilitarian consumers with traditional life styles prefer to live simpler life styles and may consider consumption necessary for survival. They are more likely to focus on utilitarian benefits (Wang et al., 2000). In contrast, "modern consumers" who tend to use surplus income to satisfy their ever-growing new desires for consumption focus more on hedonic values (Campbell, 1987).

It can be concluded from the above studies that people with different life styles may exhibit differing loyalty patterns and give differing levels of importance to hedonic and utilitarian benefits.

Thus;

RQ3: Does life style control the relationship between hedonic and utilitarian motives and brand loyalty?

Moreover, depending on research questions 1 and 2;

RQ4: Does life style control the relationship between hedonic and utilitarian motives, and brand loyalty for convenience, shopping and specialty products?

The graphic model of the study is presented in Figure 1.

\section{Figure 1}

\section{Proposed Model}

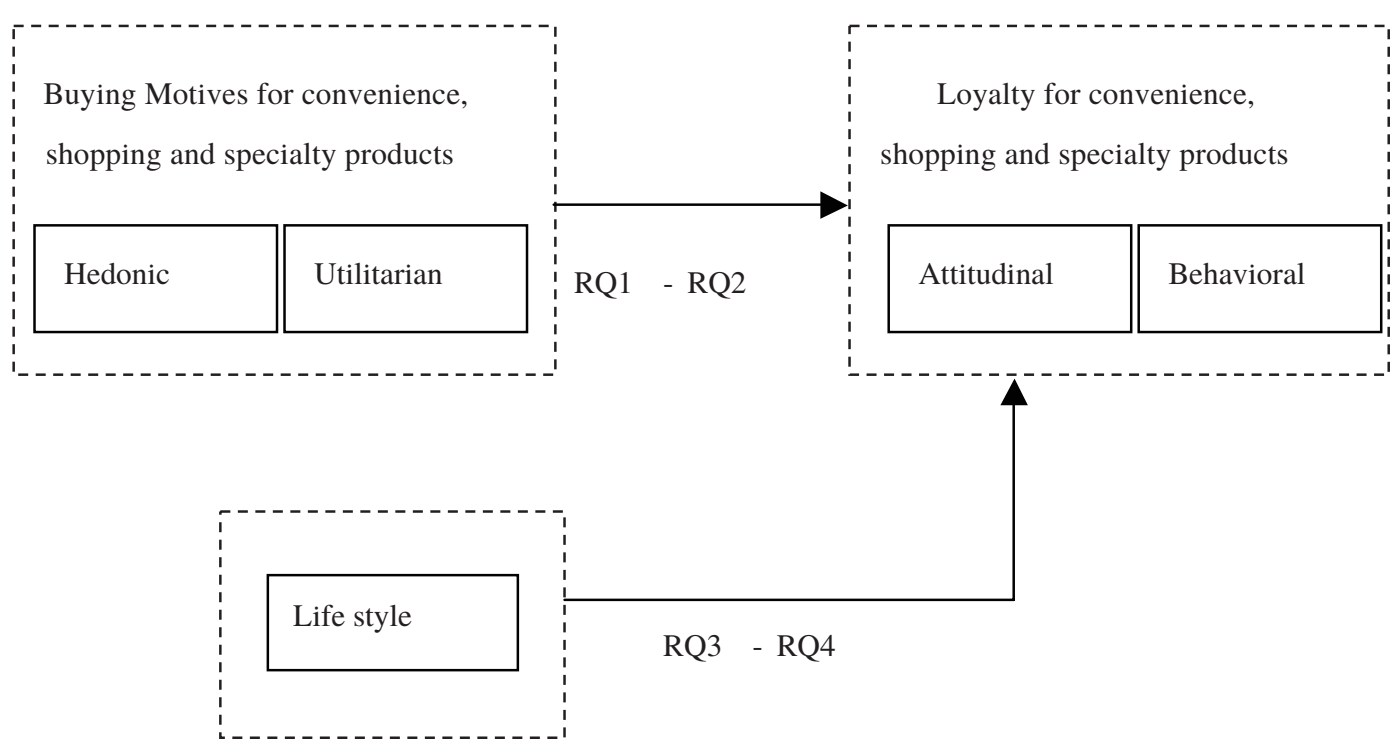




\section{METHODOLOGY}

\section{Questionnaire Development and Measurement}

The data for this study was gathered through a self-administered questionnaire. (For the measurement items, see Appendix 1.) The questionnaire was divided into five parts. The first three parts were designed to measure hedonic = utilitarian buying motives, and behavioral - attitudinal brand loyalty for convenience, shopping, and specialty product types respectively. In order to specify product types, short scenarios were written to measure frequency of purchase and price. Convenience products were presented with the following scenario: "Answer the following questions by thinking about a product that is inexpensive and that you buy every day or week such as bread, chocolate, toothpaste or pasta." For shopping products the scenario was: "Answer the following questions by thinking about a product that you perceive to be expensive and buy once a year/two years/three years such as a coat, a chair, or a kettle". For specialty products the following scenario was presented: "Answer the following questions by thinking about the product that you perceive to be very high-priced and buy rarely such as a computer, a car, a sofa set, or household appliances."

Hedonic and utilitarian buying motives were measured by the HED/UT scale of Voss et al. (2003) conducted for consumers' attitudes toward product categories. That scale is also used by To, Liao, and Lin (2007) to measure hedonic and utilitarian shopping motives. Moreover, Scarabis, Florack and Gosejohann (2006:1030) suggest that an analysis of buying motivations could be made by the use of the HED/UT scale of Voss et al. (2003). The scale is a 7-point semantic differential scale including 23 items as seen in Appendix 1 a.

Brand loyalty was measured by a three-item brand loyalty scale (Hair, Bush and Ortinau, 2000:402), two items for behavioral and one item for attitudinal loyalty. A 7-point Likert scale was used, '1' representing ' no agreement' and '7' representing 'complete agreement' (Appendix 1 b).

The fourth part of the questionnaire consists of questions measuring the respondents' life style. Life style was measured by AIO statements obtained from the literature (Kavak and Gümüşlüoğlu, 2007; Kaynak and Kara, 2002; Küçükemiroğlu, 1997; Wells and Tigert, 1977), and translated from Turkish to English previously by Kavak and Gümüşlüoğlu (2007). A 5-point Likert scale was used with '1' representing 'no agreement' and '5' representing 'complete agreement'. Finally, the last part of the questionnaire aims to measure demographic characteristics of the participants such as age, gender, and education level.

\section{Sample and Data Analysis}

Data was collected through convenience sampling from households in Ankara. The total number of respondents was 835 , with $52 \%$ female and $45 \%$ males. The respondents were relatively young, with a majority of them being below 40 years of age (79.4 \%). They had a relatively high education level, considering that $71.7 \%$ had a graduate or post graduate degree. Many of the respondents were in the middle income (49.2\%) while $25.2 \%$ had a high income. 
In order to determine the appropriateness of the data for statistical analysis, the data was tested to see if it followed a normal distribution. It was screened for normality by the Kolmogorov - Simirnov test. Variables measuring hedonic and utilitarian buying motives and brand loyalty were transformed by logarithm for normality.

Descriptive data of respondents' attitudinal-behavioral loyalty and hedonic-utilitarian motive degrees for each product categories with their ANOVA is presented in Table 1.

Table 1

Mean Differences between Product Categories: ANOVA Results

\begin{tabular}{|c|c|c|c|c|c|c|c|c|c|c|c|c|}
\hline & \multicolumn{3}{|c|}{ Behavioral Loyalty } & \multicolumn{3}{|c|}{ Attitudinal Loyalty } & \multicolumn{3}{|c|}{ Hedonism } & \multicolumn{3}{|c|}{ Utilitarianism } \\
\hline & Mean & $\mathbf{F}$ & $\mathbf{P}$ & Mean & $\mathbf{F}$ & $\mathbf{P}$ & Mean & $\mathbf{F}$ & $\mathbf{P}$ & Mean & $\mathbf{F}$ & $\mathbf{P}$ \\
\hline Between Groups & & 141.50 & .000 & & 11.27 & .000 & & 44.67 & .000 & & 8.96 & .000 \\
\hline Convenience & 3.87 & & & 5.13 & & & 4.20 & & & 5.40 & & \\
\hline Shopping & 4.71 & & & 5.35 & & & 4.03 & & & 5.71 & & \\
\hline Specialty & 5.55 & & & 5.68 & & & 4.67 & & & 5.78 & & \\
\hline
\end{tabular}

$\mathrm{P}<.01$

Table 1 allows further analysis due to the significant mean differences of brand loyalty and hedonicutilitarian buying motives for different product types.

\section{FINDINGS}

Life style dimensions were identified by using an exploratory factor analysis (EFA). The resultant factor matrix was rotated using the Varimax rotation. Only the factors that have Eigen values greater than 1 and have factor loadings greater than 0.60 were retained. The results are presented in Table 2. The EFA produced five factors explaining $41.198 \%$ of the variance. The factors were labeled as Leadership, Health Consciousness, Adventurism, Cost Consciousness, and Interest in Sport depending on previous studies (Kavak and Gümüşlüoğlu, 2007; Kaynak and Kara, 2002; Küçükemiroğlu, 1997) conducted in Turkey.

The first and second research questions were tested by a multivariate analysis of variance (MANOVA) in order to see the effects of two independent variables (i.e. hedonism and utilitarianism) on two dependent variables (i.e. behavioral and attitudinal loyalty) for three product types. Hedonism and utilitarianism measures were divided into two categories (1=low, 2=high) through a median split in order to create two groups of low and high levels of hedonic and utilitarian buying motives. F-values and significance values are presented in Table 3. Eta squares were calculated to see explained variances for each independent variable and presented in Appendix 2 and Appendix 3, together with parameter estimates and observed powers. 
Table 2

Factor Analysis for AIO Statements

\begin{tabular}{|c|c|c|}
\hline Factors & $\begin{array}{c}\text { Factor } \\
\text { Loadings }\end{array}$ & $\begin{array}{c}\text { Variance } \\
\text { Explained } \\
(\%)\end{array}$ \\
\hline Factor 1: Leadership & & 14.062 \\
\hline I am more independent than most people. & .779 & \\
\hline I think I have a lot of personal ability. & .755 & \\
\hline I think I have more self-confidence than most people. & .727 & \\
\hline I like to be considered a leader. & .550 & \\
\hline Factor 2: Health Consciousness & & 8.590 \\
\hline I buy more low calorie foods than the average housewife. & .830 & \\
\hline During the warm weather I drink low calorie soft drinks several times a week. & .760 & \\
\hline Factor 3 : Adventurism & & 7.359 \\
\hline I would like to take a trip around the world. & .763 & \\
\hline I would like to spend a year in a foreign country. & .722 & \\
\hline Factor 4: Cost Consciousness & & 5.859 \\
\hline You can save a lot of money by making your own clothes. & .701 & \\
\hline A person can save a lot of money by shopping around for bargains. & 678 & \\
\hline Factor 5: Interest in Sport & & 5.328 \\
\hline I like to watch or listen to football or basketball games. & .736 & \\
\hline I would rather go to a sports event than a dance. & 659 & \\
\hline
\end{tabular}

Kaiser-Meyer-Olkin Measure of Sampling Adequacy=0.74; $\chi^{2}=2759.87 ; d f=276 ; p=0.000$

The results of MANOVA revealed that both hedonic $($ Wilks' $\lambda=.99 ; F(1,835)=3.71, p<0.05$; eta squared $=7.96 \%$; observed power $=87 \%$ ) and utilitarian (Wilks' $\lambda=0.98 ; F(1,835)=10.55 ; \mathrm{p}<0.01$; eta squared $=13.89 \%$; observed power $=90 \%$ ) buying motives have significant effects on attitudinal loyalty for shopping products. In specialty products cases, utilitarian motives have significant effects on attitudinal loyalty (Wilks' $\lambda=0.95 ; F(1,835)=33.196, p<0.01$; eta squared $=13.89 \%$; observed power $=90 \%$ ) and hedonic motives have significant effects on behavioral loyalty (Wilks' $\lambda=0.99$; $F(1,835)=5.917, p<0.01$; eta squared $=14.53 \%$; observed power=100\%). On the other hand, for convenience products, none of the buying motives have a significant effect on either behavioral or attitudinal loyalty.

In general, these findings support the literature. For specialty products, hedonic values have significant effects on behavioral loyalty, which supports Kaul (2006) and refers to high-priced and high-involvement products usually associated with hedonic motives. On the other hand for shopping products, hedonic motives have significant impacts on attitudinal brand loyalty together with utilitarian motives. These findings are also consistent with Scarpi (2005) who stated that goal-seeking and pleasure-oriented motives are complementary. In addition, the findings also provide additional insights into the literature by considering different product categories, as well as the two components of brand loyalty. 
Table 3

Results of MANOVA and MANCOVA

\begin{tabular}{|c|c|c|c|c|}
\hline & \multicolumn{2}{|c|}{ Behavioral Loyalty } & \multicolumn{2}{|c|}{ Attitudinal Loyalty } \\
\hline & $\boldsymbol{F}$ & $P$ & $\boldsymbol{F}$ & $P$ \\
\hline \multicolumn{5}{|l|}{ Convenience } \\
\hline Hedonic & 1.830 & .177 & 2.872 & .091 \\
\hline Utilitarian & 2.160 & .142 & .042 & .837 \\
\hline Leadership & 3.136 & .077 & .000 & .993 \\
\hline Health Cons. & 6.159 & $.013 * *$ & .372 & .542 \\
\hline Adventurism & 5.082 & $.021 * *$ & .301 & .583 \\
\hline Cost Cons. & .086 & .769 & .486 & .486 \\
\hline Sport & 1.072 & .301 & .310 & .578 \\
\hline \multicolumn{5}{|l|}{ Shopping } \\
\hline Hedonic & 1.946 & .163 & 3.710 & $.051 * *$ \\
\hline Utilitarian & .016 & .901 & 10.550 & $.003 *$ \\
\hline Leadership & 1.637 & .201 & .006 & .937 \\
\hline Health Cons. & .704 & .402 & .045 & .832 \\
\hline Adventurism & .400 & .842 & 2.501 & .114 \\
\hline Cost Cons. & .709 & .400 & .672 & .413 \\
\hline Sport & .002 & .976 & .105 & .746 \\
\hline \multicolumn{5}{|l|}{ Specialty } \\
\hline Hedonic & 5.917 & $.015^{*}$ & .801 & .371 \\
\hline Utilitarian & .132 & .717 & 33.196 & $.000 *$ \\
\hline Leadership & .012 & .914 & .064 & .800 \\
\hline Health Cons. & 4.148 & $.042 * *$ & .034 & .853 \\
\hline Adventurism & 4.396 & $.036 * *$ & 4.193 & $.041 * *$ \\
\hline Cost Cons. & .557 & .457 & .900 & .764 \\
\hline Sport & 3.026 & .082 & 2.512 & .113 \\
\hline
\end{tabular}

${ }^{*} p<0.01 ; * * p<0.05$

Note: The values of hedonic and utilitarian motives for behavioral and attitudinal loyalty remained the same in MANCOVA.

MANCOVA was administered to test the effects of hedonic and utilitarian buying motives on brand loyalty by adding five life style factors (RQ3 and RQ4). F-values and significance values are represented in Table 3, and Eta Squares, Parameter Estimates, and Observed Powers are presented in Appendix 3. Results showed that the effects of hedonic and utilitarian motives on behavioral and attitudinal loyalty remained the same even after controlling for the effects of life style. In addition, life styles have effects on different types of products. For convenience products, for instance, there were significant effects of health consciousness (Wilks' $\lambda=0.99 ; F(1,835)=6.159, \mathrm{p}<0.05$; eta squared $=0.98 \%$; observed power $=65 \%)$ and adventurism $\left(\right.$ Wilks' $^{\prime} \lambda=0.99 ; F(1,835)=5.082, p<0.05$; eta-squared $\left.=0.80 ; 58 \%\right)$ 
on behavioral loyalty. For shopping products, on the other hand, none of the life style dimensions have significant effects on loyalty. As with convenience products, health consciousness and adventurism have significant effects for the specialty product category. While health consciousness has significant effects on behavioral loyalty (Wilks' $\lambda=0.98 ; F(1,835)=4.148, p<0.05$; eta squared $=0.88$; observed power $=64 \%$ ); adventurism has significant effects on both behavioral (Wilks' $\lambda=0.99 ; F(1,835)=$ 4.396, $p<0.05$; eta squared=1.00; observed power $=55 \%$ ) and attitudinal loyalty (Wilks' $\lambda=0.97 ; F$ $(1,835)=4.193, p<0.05$; eta squared $=1.03$; observed power $=62 \%)$. These results provide support for the relevant literature (i.e. Goldberg, 1982; Matzler et.al., 2005); that is, consumers' behavioral and attitudinal brand loyalties may vary based on their life styles.

\section{CONCLUSION}

This paper provides empirical support for how the effects of hedonic and utilitarian buying motives on both attitudinal and behavioral brand loyalty differ among product categories. Results showed that the effects of hedonic and utilitarian buying motives on attitudinal and behavioral brand loyalty vary for different product categories except the convenience one.

For convenience products, hedonic and utilitarian buying motives did not have significant effects on either behavioral or attitudinal loyalty. In other words, hedonic and utilitarian attributes of convenience products are not key determinants of any type of brand loyalty. It means that purchasing always from the same store and advising others to do so do not provide hedonic or utilitarian benefits to consumers. However, behavioral loyalty is influenced by health consciousness and adventurism. In other words the higher the health consciousness and adventurism, the higher the behavioral loyalty.

With regard to shopping products, both hedonic and utilitarian buying motives have significant effects on attitudinal but not on behavioral loyalty. Behavioral loyalty may not perceive hedonic or utilitarian values since searching and comparing for purchasing products may be an ordinary behavior. On the other hand, advising others as a measure of attitudinal loyalty may satisfy a person. People may advise their relatives or friends to buy a brand when they are highly satisfied with its utilitarian and symbolic benefits. This might lead to novelty and variety which are associated with hedonic values. Also, exploration of price and tangible attributes may be considered as an economic benefit which is associated with utilitarian benefits.

In the case of specialty products, as attitudinal loyalty depends on utilitarian motives, behavioral loyalty is explained hedonically. This may show that consumers want to defend their brand against negative opinions by recommending the brand to others so that they can prevent negative post-consumption evaluations such as consumer regret. This is especially crucial for specialty products as their purchase risk is relatively higher due to their higher price. On the other hand, hedonic benefits have significant effects on behavioral loyalty to specialty products. This reflects the consumers' tendency to buy the same brand repeatedly for specialty products because they enjoy their relation with the brand. In addition to these, to our surprise, the behavioral loyalties to specialty and convenience products are explained by the same life styles as health consciousness and adventurism.

Moreover we have this remarkable finding that hedonic and utilitarian motives continue to influence loyalty forms even after we control for the potential effects of life style. This result allows firms to 
shape their marketing efforts (for example, segmentation) toward consumers' loyalties using only hedonic-utilitarian benefits.

For further research, the reasons underlying attitudinal and behavioral loyalty should be investigated in areas other than hedonic and utilitarian motives and life style. Culture, psychological variables and demographics could be fertile subjects. In addition, future research must crucially emphasize the reasons for similarity of brand loyalty components for shopping and specialty products.

\section{REFERENCES}

Ahtola, O.T. (1985). "Hedonic and Utilitarian Aspects of Consumer Behavior: An Attitudinal Perspective," Advances in Consumer Research, 12(1): 7-10.

American Marketing Association, (1948). "Report of the Definitions Committee," The Journal of Marketing, 13(2): 202-217.

Amine, A. (1998). "Consumers' True Brand Loyalty: The Central Role of Commitment," Journal of Strategic Marketing, 6(4): 305-319.

Babin, B.J., Darden, R.W., and Griffin, M. (1994). "Work and/or Fun: Measuring Hedonic and Utilitarian Shopping Value," Journal of Consumer Research, 20(4): 644-656.

Bandyopadhyay, S. and Martell, M. (2007). "Does Attitudinal Loyalty Influence Behavioral Loyalty? A Theoretical and Empirical Study," Journal of Retailing and Consumer Services, 14(1): 35-44.

Batra, R. and Ahtola, O.T. (1991). "Measuring the Hedonic and Utilitarian Sources of Consumer Attitudes," Marketing Letters, 2(2): 159-170.

Campbell, C. (1987). The Romantic Ethic and the Spirit of Modern Consumerism. Oxford, England: Blackwell.

Carroll, A.B. and Ahuvia, A.C. (2006). "Some Antecedents and Outcomes of Brand Love," Marketing Letters, 17(2): 79-89.

Chaudhuri, A. and Hollbrook, M.B. (2001). "The Chain of Effects from Brand Trust and Brand Affect to Brand Performance: The Role of Brand Loyalty," Journal of Marketing, 65(2): 81-93.

Childers, T.L., Carr, C.L., Peck, J., and Carson, S. (2001). "Hedonic and Utilitarian Motivations for Online Retail Shopping Behavior," Journal of Retailing, 77(4): 511-535.

Chitturi, R., Raghunathan, R., and Mahajan, V. (2008). "Delight by Design: The Role of Hedonic versus Utilitarian Benefits," Journal of Marketing, 72(3): 48-63.

Dhar, R. and Wertenbroch, K. (2000). "Consumer Choice between Hedonic and Utilitarian Goods," Journal of Marketing Research, 37(1): 60-71. 
Dick, A. and Basu, K. (1994). "Customer Loyalty: Toward an Integrated Conceptual Framework," Journal of the Academy of Marketing Science, 22(2): 99-113.

Donovan, R.J. and Rossiter, R.J. (2003). "Store Atmosphere: An Environmental Psychology Approach,” Journal of Retailing, 58: 34-57.

Dube, L., Cervellon, M.C., and Jingyuan, H. (2003). "Should Consumer Attitudes be Reduced to Their Affective and Cognitive Bases? Validation of a Hierarchical Model." International Journal of Research in Marketing, 20: 259-272.

Dubois, B. and Laurent, G. (1999). “A Situational Approach to Brand Loyalty,” Advances in Consumer Research, 26: 657-663.

Fernie, J., Fernie, S., and Moore, C. (2003). The Principles of Retailing. Oxford: Elseiver.

Finch, E.J., Ogden, J.R., and Agden, D. (2006). Clep Principles of Marketing. New Jersey: Research and Education Association.

Fischer, E. and Arnold, S.J. (1990). "More than a Labor of Love: Gender Roles and Christmas Shopping," Journal of Consumer Research, 17(3): 333-345.

Füller, J. and Matzler, K. (2008). "Customer Delight and Market Segmentation: An Application of the Three-Factor Theory of Customer Satisfaction on Life Style Groups," Tourism Management, 29(1): 116-126.

Goldberg, M.S. (1982). "An Emprical Study of Lifestyle Correlates to Brand Loyal Behavior," Advances in Consumer Research, 9: 460-466.

Gounaris, S. and Stathakopoulos, V. (2004). "Antecedents and Consequences of Brand Loyalty: An Empirical Study,” The Journal of Brand Management, 11(4): 283-306.

Griffin, M., Babin, B.J., and Modianos, D. (2000). "Shopping Values of Russian Consumers: The Impact of Habituation in a Developing Economy," Journal of Retailing, 76(1): 33-52.

Hair, P.J., Bush, R.B., and Ortinau, D.J. (2000). Marketing Research: A Practical Approach for the New Millennium. McGraw-Hill, International Editions, Marketing and Advertising Series.

Hirschman, C.E. (1980). "Innovativeness, Novelty Seeking, and Consumer Creativity," Journal of Consumer Research, 7(3): 288-295.

Hirschman, C.E. and Holbrook, M.B. (1982). "Hedonic Consumption: Emerging Concepts, Methods and Propositions," Journal of Marketing, 46(3): 92-101.

Holton, H.R. (1958). "The Distinctions between Convenience Goods, Shopping Goods, and Specialty Goods," Journal of Marketing, 23(1): 53-56. 
Jacoby, J. and Kyner, D.B. (1973). "Brand Loyalty vs. Repeat Purchasing Behavior," Journal of Marketing Research, 10(1): 1-9.

Jin, B., Sternquis B., and Koh, A. (2003). "Price as Hedonic Shopping," Family and Consumer Sciences Research Journal, 31(4): 378-402.

Kaufman-Scarborough, C. and Lindquist, J.D. (2002). "E-Shopping in Multiple Channel Environment," Journal of Consumer Marketing, 19(4/5): 333-350.

Kaul, S. (2006). "Hedonism and Culture: Impact on Shopper Behavior,” Working Paper No. 10-04, Indian Institute of Management, October.

Kavak, B. and Gümüşlüoğlu, L. (2007). "Segmenting Food Markets: The Role of Ethnocentrism and Lifestyle in Understanding Purchasing Intentions," International Journal of Market Research, 49(1): 71- 94.

Kavak, B. and İbrahimoğlu, N. (2006). "Benlik Alg1sı ve Kendini Kurgulama Düzeyinin Marka Sadakati Üzerindeki Etkisi: Üniversite Öğrencileri Üzerinde Bir Araştırma,” Hacettepe Üniversitesi Iktisadi ve İdari Bilimler Fakülte Dergisi, 24(2):109.

Kaynak, E. and Kara, A. (2002). "Consumer Perceptions of Foreign Products: An Analysis of ProductCountry Images and Ethnocentrism," European Journal of Marketing, 33(7/8): 928-948.

Kim, J., Morris, D.J., and Swait, J. (2006). "The Six-Construct Model of True Brand Loyalty," American Academy of Advertising Conference Proceedings, 124-124.

Kim, K.C., Han, D., and Park, S.B. (2001). "The Effect of Brand Personality and Brand Identification on Brand Loyalty: Applying the Theory of Social Identification," Japanese Psychological Research, 43(4): 195-206.

Küçükemiroğlu, O. (1997). "Market Segmentation by Using Consumer Lifestyle Dimensions and Ethnocentrism: An Empirical Study," European Journal of Marketing, 33(5/6): 470-487.

Leavitt, C. and Walton, J. (1975). "Development of a Scale for Innovativeness," Advances in Consumer Research, 2: 545-554.

Lichtenstein, R.D., Netemeyer, R.G., and Burton, S. (1990). "Distinguishing Coupon Proneness from Value Consciousness: An Acquisition-Transaction Utility Theory Perspective," Journal of Marketing, 54(3): 54-67.

Mano, H. and Elliott, M.T. (1997). "Smart Shopping: The Origins and Consequences of Price Savings," Advances in Consumer Research, 24: 504-510.

Matzler, K., Hattenberger, G., Pechlaner, H., and Abfalter, D. (2005). "Lifestyle Segmentation, Vacation Types and Guest Satisfaction: The Case of Alpine Skiing Tourism," in C. Cooper, C. Arcodia, and D.W.M. Solnet (eds.), Cauthe 2004: Creating Tourism Knowledge. A Selection of Papers From Cauthe 2004, 2005. 
Odin, Y., Odin, N., and Valette-Florence, P. (2001). "Conceptual and Operational Aspects of Brand Loyalty: An Empirical Investigation,” Journal of Business Research, 53(2): 75-84.

Orth, U.R, McDaniel, M., Shellhammer, T., and Lopetcharat, K. (2004). "Market Segmentation; Brand Loyalty; Consumer Behavior; Consumer Psychology," Journal of Consumer Marketing, 21(2): 97-108.

Raju, S.P. (1980). “Optimum Stimulation Level: Its Relationship to Personality, Demographics, and Exploratory Behavior,” Journal of Consumer Research, 7(3): 272- 282.

Reichheld, F.F. and Sasser, E.W. (1990). “Zero Defections: Quality Comes to Services,” Harvard Business Review, 68(5): 105-111.

Robertson, S.T. (1967). "The Process of Innovation and the Diffusion of Innovation," Journal of Marketing, 31(1): 14-19.

Scarabis M., Florack A., and Gosejohann, S. (2006) "When Consumers Follow Their Feelings: The Impact of Affective or Cognitive Focus on the Basis of Consumers' Choice," Psychology and Marketing, 23(12): 1015-1034.

Scarpi, D. (2005). "Hedonic and Utilitarian Behavior in Specialty Shops," The Marketing Review, 5: 31-44.

Sheth, N.J. and Park, W.C. (1974). "A Theory of Multidimensional Brand Loyalty," Advances in Consumer Research, 1: 449-459.

Spillan, J.E., Küçükemiroğlu, O., and de Mayolo, C.A. (2008) "Profiling Peruvian Consumers' Lifestyles, Market Segmentation, and Ethnocentrism," Latin American Business Review, 8(4): 38-59.

Srinivasan, S.S., Anderson, R., and Ponnavolu, K. (2002). "Customer Loyalty in E-Commerce: An Exploration of Its Antecedents and Consequences,” Journal of Retailing, 78(1): 41-50.

Storgards, J.H., Tuunainen, K.V., and Öörni, A. (2009). "The Hedonic and Utilitarian Value of Digital Games at Product Category Level," in 17th European Conference on Information Systems Proceedings: 1-13.

To, P.L., Liao, C., and Lin, T.H. (2007). "Shopping Motivations on Internet: A Study Based on Utilitarian and Hedonic Value," Technovation, 27(2): 774-787.

Trijp, H.V. (1995). "Variety-Seeking in Product Choice Behavior: Theory with Applications in the Food Domain," Doctoral Thesis, Wageningen University and Research Centre.

Trijp, H.V., Hoyer, W.D., and Inman, J.J. (1996). "Why Switch? Product Category-Level Explanations for True Variety-Seeking Behavior," Journal of Marketing Research, 33(3): 281-292. 
Voss, E.K., Spangenberg, E.R., and Grohmann, B. (2003). "Measuring the Hedonic and Utilitarian Dimensions of Consumer Attitude," Journal of Marketing Research, 40(3): 310-320.

Wakefield, L.K. and Barnes, J.H. (1996). "Retailing Hedonic Consumption: A Model of Sales Promotion of a Leisure Service,” Journal of Retailing, 72(4): 409-427.

Wang, C.L., Chen, Z.X., Chan, A.K.K., and Zheng, Z.C. (2000). "The Influence of Hedonic Values on Consumer Behaviors: An Emprical Investigation In China,” Journal of Global Marketing, 14(1-2): 169-189.

Wells, W. and Tigert, D. (1977). “Activities, Interests, and Opinions,” Journal of Advertising Research, 11(4): 27-35. 


\section{APPENDIX 1}

\section{a- Utilitarian and Hedonism Scale Items}

Utilitarian

Effective/ineffective

Functional/not functional

Necessary/unnecessary

Practical/impractical

Beneficial/harmful

Useful/useless

Sensible/not sensible

Efficient/inefficient

Unproductive/productive

Handy/not handy

Problem solving/not problem solving $\underline{\text { Hedonic }}$

Not fun/fun

Dull/exciting

Not delightful/delightful

Not thrilling/thrilling

Enjoyable/ not enjoyable

Not happy/happy

Unpleasant/pleasant

Not playful/playful

Cheerful/not cheerful

Amusing/not amusing

Not sensuous/sensuous

Not funny/funny

\section{b- Loyalty Scale Items}

- If my preferred brand of this product is not available in the market/store I always shop from, I purchase the product of another brand from that place.

- When my preferred brand of this product is not available in the market/store I always shop from, I go to another place of sale in order to find that specific brand.

- I recommend the products of this brand to my friends. 


\section{APPENDIX 2}

Parameter Estimates, Eta Square and Observed Power Values for MANOVA

\begin{tabular}{|c|c|c|c|c|c|c|c|c|}
\hline & \multicolumn{4}{|c|}{ Behavioral Loyalty } & \multicolumn{4}{|c|}{ Attitudinal Loyalty } \\
\hline & $\beta$ & $\mathbf{P}$ & $\begin{array}{c}\eta^{2} \\
(\%) \\
\end{array}$ & $\begin{array}{l}\text { OP } \\
(\%) \\
\end{array}$ & $\beta$ & $\mathbf{P}$ & $\begin{array}{c}\eta^{2} \\
(\%) \\
\end{array}$ & $\begin{array}{c}\text { OP } \\
(\%) \\
\end{array}$ \\
\hline \multicolumn{9}{|l|}{ Convenience } \\
\hline Hedonic & & & 0.22 & 0.27 & & & 0.01 & 0.39 \\
\hline Low & -.031 & .26 & & & -.046 & $.07 * *$ & & \\
\hline High & $O^{a}$ & - & & & $O^{a}$ & - & & \\
\hline Utilitarian & & & 0.26 & 0.31 & & & 0.34 & 0.50 \\
\hline Low & .023 & .36 & & & -.018 & .45 & & \\
\hline High & $O^{a}$ & - & & & $O^{a}$ & - & & \\
\hline \multicolumn{9}{|l|}{ Shopping } \\
\hline Hedonic & & & 0.23 & 0.28 & & & 8.96 & 0.87 \\
\hline Low & -.029 & .18 & & & .177 & $.05 *$ & & \\
\hline High & $O^{a}$ & - & & & $O^{a}$ & - & & \\
\hline Utilitarian & & & 0.00 & 0.05 & & & 13.89 & 0.90 \\
\hline Low & -.058 & .78 & & & -.27 & $.00 *$ & & \\
\hline High & $O^{a}$ & - & & & $0^{a}$ & - & & \\
\hline \multicolumn{9}{|l|}{ Specialty } \\
\hline Hedonic & & & 14.53 & 0.78 & & & 0.08 & 0.14 \\
\hline Low & -.228 & $.00 *$ & & & -.197 & .41 & & \\
\hline High & $O^{a}$ & - & & & $O^{a}$ & - & & \\
\hline Utilitarian & & & 0.01 & 0.06 & & & 14.14 & 1.00 \\
\hline Low & .059 & .76 & & & -.104 & $.00 *$ & & \\
\hline High & $O^{a}$ & - & & & $O^{a}$ & - & & \\
\hline
\end{tabular}

$* \mathrm{p}<.05 ; * * \mathrm{p}<.10 ;$ a: This parameter is set at zero because it is the reference category. 


\section{APPENDIX 3}

Parameter Estimates, Eta Square and

\section{Observed Power Values for MANCOVA}

\begin{tabular}{|c|c|c|c|c|c|c|c|c|}
\hline & \multicolumn{4}{|c|}{ Behavioral Loyalty } & \multicolumn{4}{|c|}{ Attitudinal Loyalty } \\
\hline & $\beta$ & $\mathrm{P}$ & $\eta^{2}(\%)$ & OP $(\%)$ & $\beta$ & $\mathrm{P}$ & $\eta^{2}(\%)$ & OP $(\%)$ \\
\hline \multicolumn{9}{|l|}{ Convenience } \\
\hline Hedonic & & & 0.37 & 0.39 & & & 0.48 & 0.48 \\
\hline Low & -.259 & .20 & & & -.402 & $.05 * *$ & & \\
\hline High & $0^{a}$ & - & & & $0^{a}$ & - & & \\
\hline Utilitarian & & & 0.19 & 0.23 & & & 0.00 & 0.05 \\
\hline Low & .164 & .42 & & & -.129 & .52 & & \\
\hline High & $0^{a}$ & - & & & $0^{a}$ & - & & \\
\hline Leadership & .192 & $.06^{* *}$ & 0.43 & 0.44 & .124 & .24 & 0.18 & 0.21 \\
\hline Health Cons. & .201 & $.05^{* *}$ & 0.98 & 0.65 & .033 & .59 & 0.04 & 0.08 \\
\hline Adventurism & -.235 & $.02 *$ & 0.80 & 0.58 & .021 & .76 & 0.01 & 0.06 \\
\hline Cost Cons. & .036 & .59 & 0.04 & 0.08 & -.072 & .90 & 0.00 & 0.05 \\
\hline Sport & .135 & $.02 *$ & 0.64 & 0.61 & -.027 & .65 & 0.03 & 0.07 \\
\hline \multicolumn{9}{|l|}{ Shopping } \\
\hline Hedonic & & & 0.09 & 0.13 & & & 0.71 & 0.59 \\
\hline Low & -.278 & .12 & & & -.174 & $.07 * *$ & & \\
\hline High & $0^{a}$ & - & & & $O^{a}$ & - & & \\
\hline Utilitarian & & & 0.03 & 0.07 & & & 3.06 & 0.95 \\
\hline Low & -.229 & .20 & & & -.823 & $.00 *$ & & \\
\hline High & $0^{a}$ & - & & & $O^{a}$ & - & & \\
\hline Leadership & .199 & $.03 *$ & 0.58 & 0.55 & .190 & $.06^{* *}$ & 0.44 & 0.46 \\
\hline Health Cons. & -.050 & .38 & 0.10 & 0.14 & -.033 & .58 & 0.04 & 0.08 \\
\hline Adventurism & -.044 & .48 & 0.06 & 0.10 & .099 & .17 & 0.23 & 0.27 \\
\hline Cost Cons. & -.037 & .53 & 0.05 & 0.09 & .069 & .28 & 0.14 & 0.18 \\
\hline Sport & .050 & .92 & 0.00 & 0.05 & .065 & .25 & 0.16 & 0.20 \\
\hline \multicolumn{9}{|l|}{ Specialty } \\
\hline Hedonic & & & 1.05 & 0.88 & & & 0.06 & 0.10 \\
\hline Low & -.108 & $.05 * *$ & & & -.088 & .67 & & \\
\hline High & $0^{a}$ & - & & & $0^{a}$ & - & & \\
\hline Utilitarian & & & 0.11 & 0.15 & & & 3.59 & 1.00 \\
\hline Low & .049 & .79 & & & -.732 & $.00^{*}$ & & \\
\hline High & $0^{a}$ & - & & & $O^{a}$ & - & & \\
\hline Leadership & .019 & .82 & 0.01 & 0.05 & .138 & .16 & 0.25 & 0.29 \\
\hline Health Cons. & .199 & $.01 *$ & 0.88 & 0.64 & -.059 & .32 & 0.12 & 0.16 \\
\hline Adventurism & .125 & $.03 *$ & 1.00 & 0.55 & .151 & $.02 *$ & 1.03 & 0.62 \\
\hline Cost Cons. & -.076 & .18 & 0.22 & 0.26 & -.018 & .76 & 0.01 & 0.06 \\
\hline Sport & .088 & $.08^{* *}$ & 0.37 & 0.40 & .099 & $.07 * *$ & 0.39 & 0.42 \\
\hline
\end{tabular}

${ }^{*} \mathrm{p}<.05 ; * * \mathrm{p}<.10$; a: This parameter is set at zero because it is the reference category. 